Наталя Шалигіна,

ORCID ID 0000000242120049

Сергій Голівець

ORCID ID 0000-0003-2939-291X

Національний університет оборони України імені Івана Черняховського

\title{
РЕКОМЕНДАЦІЇ ЩОДО ВИДІЛЕННЯ НАВЧАЛЬНОГО ЧАСУ ДЛЯ ДОСЯГНЕННЯ ВІДПОВІДНОГО РІВНЯ ВОЛОДІННЯ ІНОЗЕМНОЮ МОВОЮ ЗА СТАНДАРТОМ НАТО STANAG 6001
}

У статті досліджується вітчизняний та зарубіжний досвід розподілу навчального часу для вивчення іноземних мов. Розглядається стан та ефективність мовної підготовки особового складу Збройних Сил України на інтенсивних курсах іноземних мов у Національному університеті оборони України імені Івана Черняховського. За результатами дослідження розроблено та обтрунтовано рекомендаџії щзодо виділення навчального часу, необхідного для досягнення відповідного рівня володіння іноземною мовою військовими фахівиями Збройних Сил України за стандартом HATO STANAG 6001.

Ключові слова: іноземна мова; навчальний час; мовна підготовка; стандарт НАТО STANAG 6001; стандартизований мовленнєвий рівень.

Постановка проблеми. Забезпечення якісної професійної підготовки офіцерів Збройних Сил України (далі - ЗСУ) до роботи у багатонаціональних штабах, військово-дипломатичної діяльності, участі у міжнародних миротворчих операціях, спільних військових навчаннях та інших міжнародних заходах передбачає зорієнтованість сучасної військової освіти на підготовку освічених, професійно мобільних військових фахівців, готових до адекватної взаємодії з представниками інших культурних співтовариств в умовах іншомовного середовища. Тому нині зростає потреба у військових фахівцях $з$ високим рівнем володіння іноземною мовою (далі - IM), що $\epsilon$ одним із найважливіших компонентів їхньої загальної комунікативної компетентності. Комунікативна компетентність військових фахівців є однією 3 найважливіших характеристик їх загальної професійної компетентності, тому що, по-перше, є ключовою компетентністю, по-друге, опосередковує їх специфічну діяльність, яка передбачає постійні контакти, співпрацю, взаємодію у чітко регламентованих або особливо важких умовах.

Аналіз останніх досліджень і публікацій. Останніми роками зросла актуальність дослідження комунікативної складової професійної компетентності військовослужбовців. Так, різні аспекти мовної підготовки військових фахівців досліджували О. Волобуєва, В. Гора, О. Єфімова, С. Жицька, А. Кравченко, О. Лагодинський, В. Лазарєва, П. Лозинський, О. Мамонова, Л. Маслак, В. Назаренко, А. Радванський, С. Тарасенко, А. Чирва, О. Шумський. Проте досі залишається багато невивчених проблемних аспектів підготовки фахівців військової галузі, а саме визначення науково-теоретичних засад та практичних шляхів удосконалення системи мовної підготовки офіцерів ЗСУ. Зокрема, особливої уваги потребує 
розроблення рекомендацій стосовно виділення навчального аудиторного часу, необхідного для досягнення відповідного рівня володіння IM, що й обумовлює актуальність нашого дослідження.

Мета статті - обгрунтувати рекомендації щодо виділення навчального часу, необхідного для досягнення відповідного стандартизованого мовленнєвого рівня (далі - СМР) володіння IM за мовним стандартом НАТО STANAG 6001.

Методи дослідження: аналіз наукової літератури та керівних документів 3 проблематики дослідження; аналіз стану системи мовної підготовки на інтенсивних курсах іноземних мов у Національному університеті оборони України імені Івана Черняховського; узагальнення, систематизація, аналіз та інтерпретація отриманих теоретичних й емпіричних даних.

Виклад основного матеріалу. Основним документом, що визначає національні параметри викладання і вивчення ІМ відповідно до міжнародно визнаних стандартів, є Загальноєвропейські рекомендації (ЗР) 3 мовної освіти (Common European Framework of Reference for Languages: Learning, Teaching, Assessment) (далі - CEFR). Так, відповідно до ЗР з мовної освіти існує шість рівнів володіння мовою, які були розроблені Асоціацією мовних експертів ALTE (The Association of Language Testers in Europe): інтродуктивний (Breakthrough або A1), середній (Waystage або A2), рубіжний (Threshold або B1), просунутий (Vantage або B2), автономний (Effective Operational Proficiency або C1) і компетентний (Mastery або C2). Вони охоплюють проміжок від базового до практично бездоганного рівня володіння мовою [2].

У ЗР з мовної освіти зазначається, що на вивчення ІМ рекомендовано виділяти 200 навчальних годин для досягнення одного 3 цільових рівнів. Проте існує низка факторів, які можуть вплинути на тривалість вивчення IM, зокрема:

приналежність мови до певної групи відповідно до категорії складності;

цілі та завдання вивчення IM;

інтенсивність навчального процесу;

умови навчання;

попередня мовна підготовка навчальної аудиторії;

індивідуальні особливості навчальної аудиторії (вік, професійне середовище тощо).

Дані, наведені нижче у таблиці, відображають (табл.1) скільки годин необхідно для досягнення кожного з рівнів CEFR відповідно до рекомендацій одного 3 провідних центрів вивчення англійської мови - підрозділу Кембріджського університету (Cambridge ESOL - English for speakers of other languages) [4]: 


\section{Таблиия 1}

\begin{tabular}{|c|c|}
\hline $\begin{array}{c}\text { CEFR } \\
\text { рівень }\end{array}$ & $\begin{array}{c}\text { Кількість годин } \\
\text { (приблизно) }\end{array}$ \\
\hline С2 & $1000-1200$ \\
\hline С1 & $700-800$ \\
\hline В2 & $500-600$ \\
\hline В1 & $350-400$ \\
\hline А 2 & $180-200$ \\
\hline
\end{tabular}

Фахівці

«Німецької

хвилі» (iм. Deutsche

Welle; німецька державна радіостанція та телеканал, що надають послуги у сфері вивчення німецької мови) вважають, що рівень А1 досягається після 75 годин вивчення німецької мови, А2.1 - за 150 годин, А2.2 за 225 годин. В 1.1 - 300 годин. У 1.2 - понад 400 годин [5].

У контексті нашого дослідження, вважаємо за необхідне проаналізувати рекомендації щодо розподілу навчального часу під час вивчення IM майбутніми фахівцями різних професійних галузей.

На даний час закладам вищої освіти (далі - 3ВО) надана відносна самостійність у розробленні навчальних програм та розподілі навчального часу для вивчення дисциплін, пов'язаних з вивченням IM, тому більшість кафедр IM спирається на Програму англійської мови для професійного спілкування (далі - ПАМПС) [3]. Програма призначена для ЗВО, які здійснюють підготовку фахівців 3 різних спеціальностей. Укладачами програми враховані ЗР з мовної освіти щодо рівнів володіння мовою, компетенцій користувача, можливих контекстів користування мовою, процедур складання програм та контролю результатів навчання. Програма $\epsilon$ узагальненою і може використовуватись для підготовки студентів різних спеціальностей та спеціалізацій.

Відповідно до ПАМПС кількість аудиторних годин, яка виділяється для досягнення певного рівня володіння IM, визначається з урахуванням даних, які наведено в таблиці 2.

Таблиия 2

\begin{tabular}{|c|c|c|c|c|}
\hline $\begin{array}{l}\text { Цільовий } \\
\text { рівень } \\
\begin{array}{l}\text { Вступ- } \\
\text { ний рівень }\end{array}\end{array}$ & А2 & B1 & B2 & C1 \\
\hline А1 & 200 & 400 & 600 & 850 \\
\hline А2 & - & 200 & 400 & 650 \\
\hline В1 & - & - & 200 & 450 \\
\hline В2 & - & - & - & 250 \\
\hline
\end{tabular}


Таким чином, перехід з одного рівня на наступний потребує не менше 200 годин аудиторних занять. Відповідно слухачам 3 рівнем А2 буде потрібно 400 годин для досягнення рівня В2, а з рівнем А1 - всі 600.

На сьогодні система мовної підготовки особового складу (далі - ОС) ЗСУ регламентується Концепцією мовної підготовки особового складу ЗСУ (далі - КМП ОС ЗСУ), затвердженою наказом Міністерства оборони України від 01.06.2009 р. № 267, у якій визначаються принципи мовної підготовки офіцерів, основні завдання щодо ії вдосконалення, етапи та шляхи реалізації поставлених завдань.

Як зазначається у КМП ОС ЗСУ, мовна підготовка ОС ЗСУ покликана забезпечити формування іншомовної комунікативної компетентності ОС в чотирьох видах мовленнєвої діяльності - аудіюванні, мовленні (говорінні), читанні та письмі. Рівень володіння відповідними мовними та мовленнєвими знаннями, вміннями та навичками оцінюється за шкалою стандартизованих мовленнєвих рівнів (СМР), які відповідають рівням мовленнєвої компетенції за мовним стандартом HATO "STANAG 6001" (NATO Standardization Agreement) - СМР 0 (відсутність практичного вміння), СМР 1 (виживання), СМР 2 (функціональний), СМР 3 (професійний), СMP 4 (експертний), СMP 5 (досконалий).

У КМП ОС ЗСУ опрацьовані загальні рекомендації щодо виділення навчального часу на досягнення відповідного СМР. Так, кількість аудиторних годин, яка виділяється на загальну мовну підготовку з мов, які належать до романо-германської або слов'янської групи мов, визначається 3 урахуванням даних, які наведено в таблиці 3.

\begin{tabular}{|l|c|c|c|}
\hline $\begin{array}{l}\text { Мільовий } \\
\text { рівень } \\
\text { Вступ- } \\
\text { ний рівень }\end{array}$ & до СМР 1 & до СМР 2 & до СМР 3 \\
\hline від СМР 0 & 350 & 850 & 1350 \\
\hline від СМР 1 & - & 500 & 1000 \\
\hline від СМР 2 & - & - & 500 \\
\hline
\end{tabular}

Отже, можемо зробити висновок, що для досягнення кожного наступного рівня, починаючи від СМР 1, на вивчення IM рекомендовано виділяти близько 500 аудиторних годин. На початковому етапі (СМР $0-$ CMP 1) рекомендовано 350 аудиторних годин. Однак слід пам'ятати, що ці цифри мають рекомендаційний характер і обумовлені низкою чинників.

Співвідношення рівнів володіння іноземною мовою за мовним стандартом НАТО 6001, ЗР з мовної освіти та Асоціацією мовних експертів у Європі наведено в таблиці 4: 
Таблиия 4

\begin{tabular}{|l|l|l|}
\hline $\begin{array}{c}\text { STANAG 6001 } \\
\text { (NATO \& BILC) }\end{array}$ & $\begin{array}{c}\text { Common European } \\
\text { Framework } \\
\text { (Council of Europe) }\end{array}$ & $\begin{array}{c}\text { ALTE Scale } \\
\text { (Association of Language } \\
\text { Testers in Europe) }\end{array}$ \\
\hline 2222: Limited Working & B1+: Threshold+ & $\begin{array}{l}\text { 2: Threshold User } \\
\text { Lower } \\
\text { Intermediate }\end{array}$ \\
\cline { 2 - 3 } & B1: Threshold & $\begin{array}{l}\text { 1: Waystage User } \\
\text { Elementary }\end{array}$ \\
\cline { 2 - 3 } & A2+: Waystage+ & 0: Breakthrough \\
\hline 1111: Elementary & A2: Waystage & \\
\cline { 2 - 3 } & A1: Breakthrough & \\
\hline
\end{tabular}

У контексті аналізу проблеми розподілу навчального часу для мовної підготовки ОС доцільно ознайомитися із зарубіжним досвідом у цій царині. Так, в Угорщині існують два основних мовних військових навчальних заклади - Інститут іноземних мов і Військовий центр іноземних мов за програмою «Партнерство заради миру», які $є$ структурними підрозділами Університету національної оборони ім. Міклоша Зріні. Головне завдання підрозділів - забезпечення мовної підготовки слухачів серед осіб офіцерського та сержантського складу, а також цивільних керівників і службовців, які працюють у ЗС на договірній основі. Крім того, в місцях дислокації частин ЗС Угорщини функціонує мережа регіональних центрів IM.

В Інституті іноземних мов впроваджені різні форми навчання:

повний курс, на якому слухачі вивчають IM таким же чином, як в інших цивільних профільних вузах;

10-місячний курс інтенсивного вивчення IM;

курс IM, розрахований на 300 занять, дає змогу скласти іспит на отримання CMP 2 та CMP 3 за стандартом HATO STANAG 6001;

курс без відриву від служби (вісім занять на тиждень) для вивчення англійської, французької, німецької, російської, італійської, іспанської, а також мов сусідніх держав, наприклад української та хорватської.

У регіональних центрах військовослужбовці вивчають англійську мову в групах з 7-12 осіб по 24 години на тиждень. Зазвичай тривалість навчання становить 10 місяців, протягом яких слухачі, які не вивчали цю мову раніше, отримують проміжний (intermediate) рівень знань. Тобто тільки для досягнення СМР 2 слухачам відводиться 1000-1100 годин навчального часу. За умови успішного складання фінальних іспитів вони можуть продовжити навчання у Військовому центрі іноземних мов [1].

У США провідним навчальним закладом, у якому здійснюється мовна підготовка військовослужбовців, $є$ Військовий інститут іноземних мов, розташований у місті Монтерей (штат Каліфорнія). Його завдання організація навчання IM в інтересах забезпечення національної безпеки як на 
території США, так і за кордоном; проведення науково-дослідних робіт у галузі військової мовної освіти з метою вдосконалення процесу навчання; розроблення стандартів тестування і оцінки рівня знань. Філії інституту є у Вашингтоні та Сан-Антоніо. Навчання здійснюється на наступних курсах: базовому, просунутому і спеціальному. В інституті викладають близько 30 мов. Тривалість навчання становить від 2 (для просунутого і спеціального курсів) до 63 (для базового курсу) тижнів. Залежно від їх складності мови розділені на чотири категорії. Найскладніші належать до 4-ї категорії (арабська, корейська, китайська, японська та низка інших східних мов). До 3-ї категорії - російська, фарсі, сербо-хорватска, пушту, даруй та інші, до 2-ї німецька, а до 1-ї - романські мови. Передбачено періодичне проведення контрольного заняття 3 оцінкою рівня засвоєння програм навчання. Як свідчить багаторічна практика, до 15 відсотків слухачів не витримують такого навантаження і відраховуються на різних етапах навчання.

У США більшість військовослужбовців попередньо не вивчали цільову мову, тому їм доводиться вивчати мови з початкового рівня. Для досягнення необхідного рівня володіння мовою американцям необхідна наступна кількість навчального часу (табл. 5):

\begin{tabular}{|l|l|l|l|l|l|}
\hline $\begin{array}{l}\text { Мови за категоріями } \\
\text { складності }\end{array}$ & \multicolumn{1}{|c|}{ I } & \multicolumn{1}{|c|}{ II } & \multicolumn{1}{|c|}{ III } & \multicolumn{1}{|c|}{} \\
\hline Приклади & $\begin{array}{l}\text { Французька, } \\
\text { Іспанська, } \\
\text { Датська }\end{array}$ & $\begin{array}{l}\text { Німецька, } \\
\text { Румунська, } \\
\text { Індонезійсь } \\
\text { ка }\end{array}$ & $\begin{array}{l}\text { Російська, } \\
\text { Турецька, } \\
\text { Перська }\end{array}$ & $\begin{array}{l}\text { Арабсь } \\
\text { ка, } \\
\text { Корейс } \\
\text { ька, } \\
\text { Китайс } \\
\text { ька }\end{array}$ \\
\hline $\begin{array}{l}\text { Необхідно } \\
\text { тижнів від }\end{array}$ & $\begin{array}{l}0 \text { до 2 } \\
2+\text { до } \\
2+\end{array}$ & 25 & 34 & 47 & 63 \\
\cline { 2 - 6 } & $\begin{array}{l}2+\text { до } \\
3\end{array}$ & 18 & 26 & 36 & 47 \\
\hline
\end{tabular}

Навчання передбачає 30 годин навчальних занять на тиждень під керівництвом викладача, а також 3 години самостійної підготовки щоденно. Наприклад, для досягнення володіння французькою мовою на рівні СМР 2 необхідно 750 годин під керівництвом викладача і 375 годин самостійної підготовки.

Крім того, фахівці з мовної підготовки США вважають, що неможливо студенту, навчаючись самостійно, досягти рівня СMP 3. Необхідно мати додатково досвід використання мови у роботі та/або відповідному мовному середовищі.

Європейський досвід може значно відрізнятись від американського, тому що вивченню мов приділяється значна увага у загальноосвітніх 
національних програмах, а також існує більше можливостей спілкуватись 3 носіями мов. Для прикладу, у порівняльній таблиці наведено кількість годин, яка вважається необхідною для досягнення цільового рівня СМР 2 (B1+) в різних країнах світу (табл. 6):

\begin{tabular}{|c|c|c|c|c|}
\hline $\begin{array}{c}\text { Міжнародний досвід } \\
\text { Рівень }\end{array}$ & CEFR & США & Угорщина & Уабраӥна 6 \\
\hline CMP 2 (B1+) & 500 & $\begin{array}{c}750 \\
(+375 \\
\text { самостійної } \\
\text { підготовки) }\end{array}$ & 1000 & $\begin{array}{c}(+150 \\
\text { самостійної } \\
\text { підготовки })\end{array}$ \\
\hline
\end{tabular}

Досвід мовної підготовки на інтенсивних курсах IM для ОС ЗСУ на базі Навчально-наукового центру іноземних мов Національного університету оборони України імені І. Черняховського свідчить про наявність очевидних позитивних результатів навчання в межах навчальних годин, рекомендованих КМП ОС ЗСУ для досягнення певного цільового рівня. Так, коефіцієнт ефективності підготовки на інтенсивних курсах ІМ у період з 2009 по 2017 рік варіювався у межах 55-85 відсотків, що дає підстави оцінювати курси як ефективні або високоефективні.

Водночас існують певні недоліки 3 огляду на обсяг виділеного навчального аудиторного часу та систему організації навчання на курсах для досягнення відповідного цільового рівня.

Так, однією із найважливіших проблем $є$ перерване навчання між курсами з цільовими рівнями СМР 1 та СМР 2, що значно уповільнює процес оволодіння IM ОС ЗСУ та досягнення мінімально-необхідного “функціонального" рівня СMP 2. В першу чергу це пов'язано із неможливістю бути відірваним від служби для проходження курсів IM. За таких умов СМР 3 та СМР $4 \epsilon$ практично недосяжними для ОС ЗСУ.

Зважаючи на це, ми рекомендуємо запровадити дворівневі інтенсивні курси IM з цільовим рівнем СМР 2 для ОС зі вступним рівнем СМР 0, що становить 850 годин (350 годин - СМР 0-СМР 1, 500 годин - СМР 1-СМР 2); 3 цільовим рівнем СМР 3 для ОС зі вступним рівнем СМР $1-1000$ годин (500 годин - СМР 1-СМР 2, 500 годин - СМР 2-СМР 3).

Варто також наголосити на необхідності створення сприятливих умов для вивчення IM у процесі проходження служби на посадах у військах, а саме:

організація практичних занять IM для ОC;

забезпечення ОС інформаційними ресурсами та навчально-методичними матеріалами для самостійної мовної підготовки з метою підтримання раніше отриманих мовних знань і подальшого розвитку практичних умінь та навичок володіння IM.

Висновки та перспективи подальших наукових досліджень. Проблема розподілу навчального аудиторного часу для вивчення іноземної мови 3 метою досягнення певного стандартизованого мовленнєвого рівня відповідно до мовного стандарту HATO STANAG 6001 у полі зору багатьох 
вітчизняних і зарубіжних науковців та викладачів-практиків. На тривалість вивчення іноземної мови впливає низка чинників: приналежність мови до певної групи відповідно до категорії складності; цілі та завдання вивчення іноземної мови; інтенсивність навчального процесу; умови навчання; попередня мовна підготовка та індивідуальні особливості навчальної аудиторії. Водночас кількість навчальних годин для досягнення певного стандартизованого мовленнєвого рівня обумовлена особливостями системи мовної підготовки у Збройних Силах та офіційними керівними документами у галузі військової мовної освіти. Дослідження тематики та обсягу мовного матеріалу, необхідного для вивчення в межах кожного стандартизованого мовленнєвого рівня, $є$ перспективою наших подальших наукових розвідок.

\section{ЛІТЕРАТУРА}

1. Вікторова Л. В. Модернізація іншомовної підготовки співробітників сектора безпеки у контексті загальноєвропейських інтеграційних процесів [Електронний ресурс]/ Л. В. Вікторова// Наукові записки [Ніжинського державного університету ім. Миколи Гоголя]. Психолого-педагогічні науки. - 2014. - №2. - С. 62-67. Режим доступу: http://nbuv.gov.ua/UJRN/Nzspp_2014_2_13

2. Загальноєвропейські рекомендації 3 мовної освіти : вивчення, викладання, оцінювання / наук. ред. укр. видання д. пед. н., проф. С. Ю. Ніколаєва. - К.: Ленвіт, 2003. $273 \mathrm{c}$.

3. Програма 3 англійської мови для професійного спілкування / кол. авт.: Г. Є. Бакаєва, О. А. Борисенко, І. І. Зуєнок та ін. - К.: Ленвіт, 2005. - 119 с.

4. CEFR and ALTE Can Do statements / [Електроний ресурс]. - Режим доступу: http://www.cambridgeenglish.org/exams-and-tests/cefr//

5. Deutsche Welle. Deutschkurse.dw-world.de. / [Електроний ресурс]. - Режим доступу: http://deutschkurse.dw-world.de/dw_static_content/langerklaerung_en.html

\section{REFERENCES}

1. Viktorova, L. V. (2014). Modernizatsiia inshomovnoi pidhotovky spivrobitnykiv sektora bezpeky u konteksti zahalnoievropeiskykh intehratsiinykh protsesiv [Elektronnyi resurs] [Modernization of Foreign Language Training of Security Sector Employees in the Context of Pan-European Integration Processes [Electronic resource]]. Naukovi zapysky [Nizhynskoho derzhavnoho universytetu im. Mykoly Hoholia], 2, 62-67, Mode of access: http://nbuv.gov.ua/UJRN/Nzspp_2014_2_13 (in Ukrainian).

2. Nikolaieva, S. Yu. (Ed.). (2003). Zagalnoievropeiski rekomendatsii z movnoi osvity: vyvchennia, vykladannia, otsiniuvannia [Common European Framework of Reference for Languages: Learning, Teaching, Assessment]. K.: Lenvit. (in Ukrainian).

3. Bakaieva, G. Ie., Borysenko, O. A., Zuienok, I. I. (2005). Programa z angliyskoi movy dlia profesiynogo spilkuvannia [English language academic program for professional communication]. K.: Lenvit. (in Ukrainian).

4. CEFR and ALTE Can Do statements / [Electronic resource]. - Mode of access: http://www.cambridgeenglish.org/exams-and-tests/cefr//. (in English).

5. Deutsche Welle. Deutschkurse.dw-world.de. / [Electronic resource]. - Mode of access: http://deutschkurse.dw-world.de/dw_static_content/langerklaerung_en.html. (in German).

\section{PЕЗЮМЕ}

Наталья Шалыгина, Сергей Голивец

Национальный университет обороны Украины имени Ивана Черняховского 


\section{Рекомендации по выделению учебного времени для достижения соответствующего уровня владения иностранным языком по стандарту НATO STANAG 6001}

В статье исследуется отечественный и зарубежный опыт распределения учебного времени для изучения иностранных языков. Рассматривается состояние $u$ эффективность языковой подготовки личного состава Вооруженных Сил Украины на интенсивных курсах иностранных языков в Национальном университете обороньл Украины имени Ивана Черняховского. По результатам исследования разработань и обосновань рекомендации по выделению учебного времени, необходимого для достижения соответствующего уровня владения иностранным языком военными специалистами Вооруженных Сил Украины по стандарту НАTO STANAG 6001.

Ключевые слова: иностранный язык; учебное время; языковая подготовка; стандарт НАTO STANAG 6001; стандартизированный речевой уровень.

\section{SUMMARY}

Natalia Shalyhina, Serhii Holivets

National Defense University of Ukraine named after Ivan Cherniakhovskyi

\section{Recommendations on the allocation of academic hours for attaining an appropriate level of foreign language proficiency in accordance with the NATO standard STANAG 6001}

Introduction. The communicative competence of military specialists is one of the most important characteristics of their general professional competence. However, there are still many unresearched aspects of this problem, namely the scientific and theoretical foundations and practical ways of improving the system of language training of officers of the Armed Forces of Ukraine. In particular, the development of recommendations for the allocation of academic hours for attaining an appropriate level of foreign language proficiency requires special attention.

Purpose. Development and substantiation of recommendations for the allocation of the training time required to achieve the appropriate level of foreign language proficiency.

Methods. The system of general scientific and special methods of theoretical and empirical research was used, namely: analysis of scientific literature on the problem of research, systematization and generalization of scientific information, monitoring of the existing system of training of military specialists in different countries, analysis and interpretation of the obtained theoretical and empirical data.

Results. The article examines the domestic and foreign experience in the problem of the distribution of academic hours for the study of foreign languages. According to the results of the study, recommendations for the allocation of the training time required to reach the appropriate level of foreign language proficiency by military experts of the Armed Forces of Ukraine according to the NATO Standard STANAG 6001 have been developed and substantiated.

Originality. The current state and efficiency of language training of military specialists of the Armed Forces of Ukraine at intensive courses of foreign languages at the National Defense University of Ukraine named after Ivan Chernyakhovskyi have been considered.

Conclusion. The study of the topics and amount of linguistic material required to study within each standardized language proficiency level is a prospect for further scientific research in this direction.

Key words: foreign language; academic hours; language training; NATO standard STANAG 6001; standardized language proficiency level. 